\title{
Engineering Students: What factors effects their entrepreneurial intention?
}

\author{
Lutfiah Natrah Abbas ${ }^{1}$ \\ ${ }^{1}$ (Faculty of Technical \& Vocational Education, Universiti Tun Hussein Onn Malaysia, Malaysia)
}

\begin{abstract}
Despite the large number of studies on entrepreneurial intention among tertiary students, there is a lack understanding of factors that lead entrepreneurial intention among engineering students. The objective of this quantitative study examines the factors that contribute entrepreneurial intention of engineering student by applied Theory of Planned Behavior (TPB). Participants were 328 final year engineering students from a public technical university in Malaysia. Using Entrepreneurial Intention Questionnaire (EIQ), the descriptive analyses found that entrepreneurial intention of engineering students were in moderate level. T-test and Annova One Way analyses revealed that no statistical difference of entrepreneurial intention of male and female, but engineering courses taken in the university play a role in explaining entrepreneurial intention. The study confirmed that students in engineering field did not possess high entrepreneurial intention. Among the three determinants in TPB that were examined, the highest mean score was recorded in perceived behavioral control. The study suggests that university management should provide resources planning of the university that related to entrepreneurship. The study contributes to the literature about the impact of entrepreneurship initiatives in Malaysia, particularly in a technical higher institution setting.
\end{abstract}

Keywords - entrepreneurship, engineering, Planned Behavior, Entrepreneurial Intention Questionnaire, business career.

\section{INTRODUCTION}

The purpose of this paper is to investigate the impact of an entrepreneurship exposure on the entrepreneurial intention of engineering students. This study will also examine the significance of different demographic variables in engineering students' entrepreneurial intention.

\section{LITERATURE}

\section{Research Framework}

This study is underlying the components in the theory of planned behavior (TPB) developed by [4]. The TPB model explains that intention is a good predictor of behavior and there are three factors to consider: (a) personal evaluation of behavior (attitude towards behavior), (b) social pressure (subjective norm), and (c) perceived capability to perform behavior (perceived behavioral control). The importance of these three components in TPB varies across situations and behaviors that are investigated [5]. The personal factor is the individual's attitude towards the behavior, which refers to an individual's negative or positive evaluation to perform the particular behavior or interest. People will perform a specific behavior based on their perception. If they view the performance favorably, they will perform it but they will not perform once they view unfavorably [6].This factor is influenced by the total behavioral beliefs [7]. Subjective norm refers to perceived social pressures to perform or not to perform the given behavior [4]. [5] noted that social norms have a significant predictor for intention. Encouragement from other people, particularly family and friends is one reason why people involve in business. Perceived behavioral control refers to the perceived easiness or difficulty of an individual becoming an entrepreneur [6]. It related to the individual perception or confidence in ability to perform the behavior. The person more inclined to perform the behavior when he believes he can succeed in a specific action [8]. 


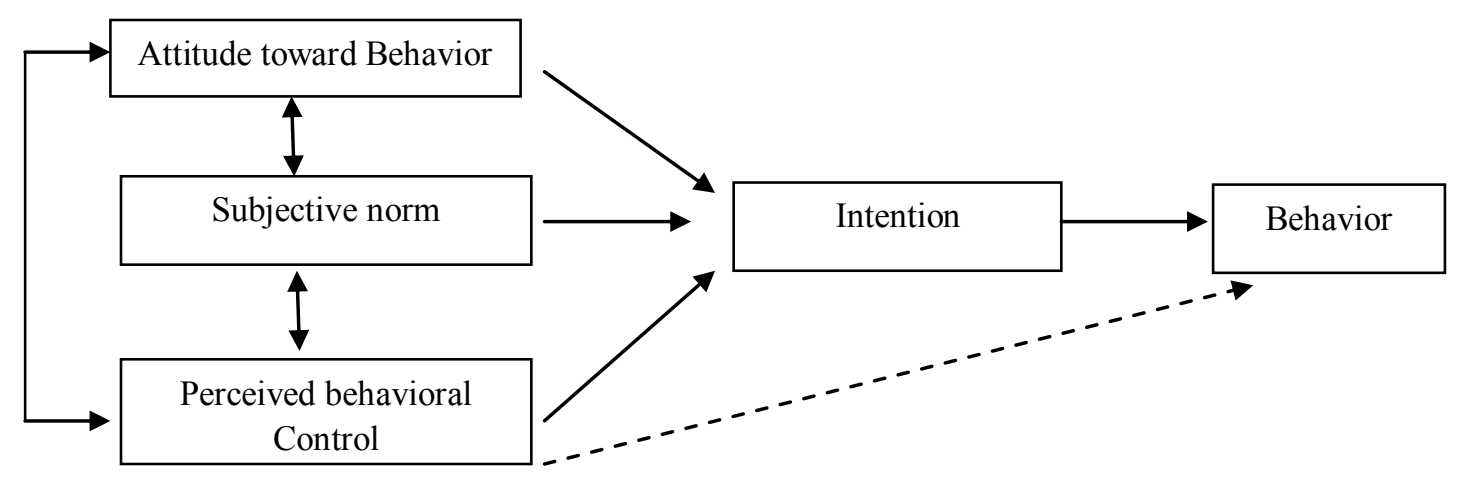

Figure 1:. The theory of planned behavior

\section{Entrepreneurial Intention}

Entrepreneurial intention refers to an individual's personal desire to create a new firm or a new value driver within existing organizations [9]. [10] argued that entrepreneurial intention falls into the following two categories: (a) impulsive and (b) deliberate. Impulsive entrepreneurial intention refers to intention without realistic control of business resources. It can be influenced by personal characteristic, culture, or demographic factors. Deliberate entrepreneurial intention is the willingness of the individual to venture into business due to the feasibility of entrepreneurial behaviors. It depends on external resources such as prior experience or network building. Entrepreneurial intention studies have received extensive attention from researchers ever since it has been suggested by meta-analyses that intention is a reliable predictor of actual behavior [11].

\section{Factors leading to entrepreneurial intention}

[12] emphasized that entrepreneurship education and training programs are aimed directly at stimulating entrepreneurship (mostly directed to entrepreneurs whose aim is the development of opportunityseeking within firms). The experts in the field of education for entrepreneurship, nominated by the national authorities under the Multiannual Programme for Enterprise and Entrepreneurship suggested that the objectives, contents, and methods of teaching entrepreneurship in the tertiary level should differ based on the level of education [13].

At the undergraduate level, the objectives mainly focus on awareness and motivation elements. At this level, entrepreneurship contents are to stimulate students' mindset in self-employment and business start-ups. At the graduate and postgraduate level, the objective is to deliver the necessary skills that relate to entrepreneurship. The contents involved are practical tools such as a business plan, marketing plan, and finance [13].

The components in entrepreneurship education (objectives, contents, and teaching methods) are essential because many scholars reported positive outcomes in the entrepreneurial intention. [14] studied how entrepreneurship education impacted students' entrepreneurial intention in a French university. The study focused on the changes of students' attitudes and mindset towards entrepreneurship upon completion of the course. The result showed that entrepreneurship education was able to change positively students' perceptions, intentions, and attitudes.

This finding was confirmed by [15]. The study reported that entrepreneurship education has a positive impact on students' perception when the contents of the education seem relevant. It also noted the instructors themselves as well as their innovative strategies influence student perception towards entrepreneurship. Rather than simply learning about the world of business, entrepreneurship education allows for a richer experience because it involves effective experiments, explorations, creative thinking, and problem solving that are necessary for graduates [16].

Previous studies also highlighted environmental factors in explaining entrepreneurial intention, which included family decisions and family backgrounds. [17] noticed that individuals who come from families that own businesses possess greater entrepreneurial intention in Malaysia. They dubbed this factor as the effective environment. Family activities in business present intimate role models for graduates, and such graduates seem more likely to choose entrepreneurship as their career than graduates who come from families that do not run businesses.

[18] pointed out that personal experience and individual background dictate an individual's level of entrepreneurial self-efficacy and entrepreneurial intention. This finding suggests that experience controls selfefficacy and intention in entrepreneurship. Similarly, [19] conducted a study in a university in Pakistan. The 
study, using a descriptive analysis and Pearson's correlation coefficient, revealed that personal experience or familial experience in business influenced individual entrepreneurial intention. According to this notion, familial experience gives exposure to the business realm and improves an individual's knowledge about changing market trends.

A systematic literature presented by [20] explained entrepreneurial intention factors in another waypositive or negative. The positive refers to factors that contribute to business creation, and negative refers to factors that do not contribute to business creation. [20] concluded that factors such as family or spouse involvement in business, emigration, work experience, and ethnic minorities are the positive effects, while the negative effect is gender differences.

There was a large volume of published studies describing the role of demographic factors in entrepreneurial intention. [21] reported that African male graduates had a higher intention to become entrepreneurs than other races and ethnicities. This finding was parallel to the findings of [18] who noted that female students in middle school and at the tertiary level possess less entrepreneurial self-efficacy than males do at the same levels.

[22] however, provided different results for the role of gender. His analyses on 390 responses from undergraduate students in business school at Pace University pointed out there were no significant differences in entrepreneurial intention between male and female students. The study explained that the increasing number of female students at Pace University provided them with the same opportunity as their male counterparts in the exposure of entrepreneurship.

\section{Entrepreneurship and engineering students}

There is speculation that entrepreneurship awareness and exposure is especially lacking among graduates in nonbusiness field in higher learning settings. This was proved by [23] in their comparative study of students majoring in entrepreneurship, and the medical field. They noticed that medical students had a lower intention to go into business than entrepreneurship students. In another study, [7] pointed out that that attitude toward behavior, perceived behavioral control, and subjective norm were not significant to the entrepreneurial intention of respondents from social science, engineering and science field. [13] also mentioned that non business students, especially from technical disciplines, have strong technical skills and frequently have strong product ideas but they are weak in the area of commercialization and marketing.

\section{METHODOLOGY AND RESULTS}

Methodology

The EIQ was self-administered by the researcher to 328 final year students from three engineering faculties: the civil engineering faculty, the electrical faculty, and the mechanical faculty. This instrument has been translated into the Malay language using back-to-back translation.

\section{Results}

The mean score from 1.00 to 2.50 were determined as low entrepreneurial intention, 2.51 to 5.50 were determined moderate entrepreneurial intention, and 5.51 and above classified as high entrepreneurial intention. The results revealed that the overall mean score of the entrepreneurial intention of the respondents in moderate level (mean= 3.47, S.D= 0.65). The highest mean score of the respondents was perceived behavioral control (3.82), the second highest was entrepreneurial intention (3.45), the third highest was attitude toward behavior (3.38) and the lowest mean score was subjective norm (3.22).

The t-test indicated that the difference between the mean score of male and female did not achieve significance at the 0.05 level, $(\mathrm{Sig}=0.034 ; \mathrm{F}=4.53)$. This result explained that there is no significance difference between male and female in their entrepreneurial intention (Table 1).

Table 1: Comparison of Male and Female on Entrepreneurial intention, Subjective norms, Attitude toward behavior, and Perceived Behavioral Control ( $\mathrm{n}=158$ males and 170 females)

\begin{tabular}{|c|c|c|c|c|c|}
\hline Variable & Mean & $\mathrm{SD}$ & $\mathrm{t}$ & $\mathrm{d} f$ & $P$ \\
\hline $\begin{array}{r}\text { Entrepreneurial intention } \\
\text { Male } \\
\\
\end{array}$ & $\begin{array}{l}3.42 \\
3.48\end{array}$ & $\begin{array}{l}0.715 \\
0.721\end{array}$ & -0.750 & 326 & 0.454 \\
\hline $\begin{array}{r}\text { Subjective norm } \\
\text { Male } \\
\text { Female }\end{array}$ & $\begin{array}{l}3.19 \\
3.26\end{array}$ & $\begin{array}{l}1.010 \\
0.965\end{array}$ & -0.573 & 326 & 0.946 \\
\hline $\begin{array}{c}\text { Attitude toward behavior } \\
\text { Male } \\
\text { Female }\end{array}$ & $\begin{array}{l}3.47 \\
3.31\end{array}$ & $\begin{array}{l}0.822 \\
0.699\end{array}$ & 1.839 & 309.36 & 0.067 \\
\hline
\end{tabular}


Engineering Students: What factors effects their entrepreneurial intention?

\begin{tabular}{llllll}
\hline Perceived behavioral control & & & 0.067 & 311.17 & 0.946 \\
Male & 3.83 & 0.726 & & & \\
Female & 3.82 & 0.627 & & & \\
\hline
\end{tabular}

A statistically significant difference was found among the three engineering courses, $F(2,327)=41.267, \mathrm{P}<$ .05. Table 2 shows that the mean entrepreneurial intention for electrical engineering students is $3.86,3.43$ for civil engineering students, and 3.14 for mechanical engineering students. Games-Howell post hoc test (Table 3) indicate the significant mean differences on entrepreneurial intention between Electrical Engineering students and Civil engineering student ( $\mathrm{p}<.05, d=0.38$ ), Electrical Engineering students and Mechanical Engineering ( $\mathrm{p}<.05, d=0.62)$, and Civil Engineering and Mechanical Engineering $(\mathrm{p}<.05, d=0.24)$.

Table 2: Means and Standard Deviation Comparing Entrepreneurial Intention Among Three Educational Groups

\begin{tabular}{llll}
\hline Educational background & $\mathrm{N}$ & Mean & SD. \\
\hline Electrical Engineering & 109 & 3.86 & 0.05 \\
Mechanical Engineering & 111 & 3.14 & 0.60 \\
Civil Engineering & 108 & 3.43 & 0.58 \\
\hline
\end{tabular}

Table 3: One Way Analysis of Variance Summary Table Comparing Variable Entrepreneurial Intention

\begin{tabular}{|c|c|c|c|c|c|}
\hline Variables & $\mathrm{d} f$ & $\mathrm{SS}$ & $M S$ & $F$ & $p$ \\
\hline \multicolumn{6}{|l|}{ Entrepreneurial intention } \\
\hline Between groups & 2 & 23.82 & 11.91 & 26.74 & 0.000 \\
\hline Within groups & 325 & 144.78 & 0.44 & & \\
\hline Total & 327 & 168.60 & & & \\
\hline \multicolumn{6}{|l|}{ Subjective norm } \\
\hline Between groups & 2 & 35.80 & 17.90 & 20.61 & 0.000 \\
\hline Within groups & 325 & 282.20 & 0.87 & & \\
\hline Total & 327 & 318.00 & & & \\
\hline \multicolumn{6}{|l|}{ Attitude toward behavior } \\
\hline Between groups & 2 & 27.89 & 13.95 & 27.81 & 0.000 \\
\hline Within groups & 325 & 162.96 & 0.50 & & \\
\hline Total & 327 & 190.85 & & & \\
\hline \multicolumn{6}{|l|}{ Perceived behavioral control } \\
\hline Between groups & 2 & 27.82 & 13.91 & 37.12 & 0.000 \\
\hline Within groups & 325 & 121.76 & 0.37 & & \\
\hline Total & 327 & 149.58 & & & \\
\hline
\end{tabular}

\section{DISCUSSION}

The result indicated that entrepreneurial intention of the engineering students is in moderate level. This result was congruent with the result of the previous studies [24]; [23] that found entrepreneurial intention students of non-entrepreneurship students lower than students majoring in entrepreneurship. Study by [3] pointed out there are five elements that contribute to the lacking of development entrepreneurial intention among university students, namely educational resources, motivation in training, teaching methods and regulations, foresight, and hardware resources. Of all these elements, the study highlighted the educational resources as the essential one. The educational resources include the weak of curriculum, inappropriate lesson plans and contents, and less of references books. Lacking of educational resources may create ineffective entrepreneurship program that conducted by the learning institutions.

[24] in his study found that non-commerce students in Malaysian polytechnics were not interested in studying the entrepreneurship module due to two reasons. First, the nature of the curriculum that too focuses on theories and outdated. Second, because of the entrepreneurship curriculum failed to foster entrepreneurship culture. Malaysia is lacking educators that specialize in entrepreneurship field [25]. Majority of the entrepreneurship educators did not have experiences in business field or from other courses than entrepreneurship. This was proven by [24] in his interviews to entrepreneurship lecturers in public learning institutions in Malaysia. The study revealed that only $20 \%$ of lecturers had attended a course in entrepreneurship, and a few of them have experience in teaching entrepreneurship.

Moreover, according to [13], the content and aims of the entrepreneurship education should not be confused with general economic studies. [13]suggested that higher learning institutions should embedded activities based on learning by doing such as develop virtual firms, providing specific training on how to start a business, and foster students' awareness of self-employment as a career option. Although all four variables of TPB components indicated the moderate level, the highest mean score was recorded in perceived behavioral control $(M=3.82)$. Students with high perceived behavioral control believe they can succeed in business and intend to involve in business in their future. According to [26], perceived behavioral control can be influenced by intimate sources such as role models, enactive mastery, and social persuasion. [28] asserted that universities should be position themselves as a hub of entrepreneurship. Pedagogical approach in universities considered as 
effective way to help students perceive the entrepreneurship as career. As students expose to the experiences from successful entrepreneurs, their perception to entrepreneurship may be increased [29].

However, in Malaysia, the collaboration between higher learning institutions and entrepreneurs is in low level. [25] reported that this scenario was due to several reasons. First, it is difficult to get commitment of entrepreneurs. Many entrepreneurs busy with their business, and as a result, it difficult to arrange time for meeting or discussion. Second, is because of the low incentives. The fees incentives for entrepreneurs as speakers offered by higher learning institutions are based on qualifications. Some of successful entrepreneurs did not attain high academic achievement which makes them get lower fees according the time that they constituted.

Another factor need to be considered is the thinking of people about the career in entrepreneurship. Qualitative finding by [24] highlighted that the perception of majority parents to career in entrepreneurship was low. Majority of the parents hope that their children hold a career which in line with their qualification and employed in such corporate sectors or government agencies.

This study highlighted that there was no significance difference between male and female in their entrepreneurial intention. This finding is different to prior studies ([21]; [18]) which reported that male graduates had a higher intention to become entrepreneurs than female graduates. This could be because the enrollment of female students in engineering field in Malaysia. Malaysian Ministry of Higher Learning reported that, the ratio of enrollment male students to female students in technical and science was 48:52 in year 2009 and 2010 [27]. It showed that the female population was higher than the male students in engineering field. This finding also reflected that the female students perceived that their university provides them with the necessary knowledge, exposure, and opportunity as male students in the university.

The Annova One Way analyses indicated that statistically significant difference was found among the three engineering courses. This concluded that engineering subject in the course such as project management can help students gain experience in entrepreneurship as well.

\section{CONCLUSION}

The results of this study confirmed the results of previous studies that students in engineering field did not possess high entrepreneurial intention. Among three determinants in TPB that were examined, the highest mean score was recorded in perceived behavioral control. This means engineering students will possess higher entrepreneurial intention when they see business is interesting career. The study suggest that university management should provide resources planning of the university that related to entrepreneurship, such as consider the capability of entrepreneurship lecturers, references books, and techno center at the university. In addition, the university can add on more practical activities that enable students to get more exposure to the real world of entrepreneurs, such as a business try out during graduation day, visiting successful entrepreneurs and inviting guest speakers from companies. However, the study focused only on entrepreneurial intention of engineering students at one public university in Malaysia. Therefore, the results of this study were limited to this population and generalization cannot be made to other public universities in Malaysia. For the purpose of generalizing the results, more studies that involve larger samples are needed. Overall, this study confirmed that the theory planned behavior is appropriate to examine entrepreneurial intention at higher learning institution.

\section{REFERENCES}

[1]. S.T. Muench, Self-managed learning model for civil engineering continuing training. Journal of Professional Issues in Engineering Education and Practice, 132(3), 2006, 1-8.

[2]. M.N. Ab. Rahman, J. Ghani, A.R. Ismail \& R. Mohd Zain, Engineering students towards entrepreneurship awareness. Research Journal of International Studies, 18, 2011, 48-58.

[3]. M. R. Soleimanpour, S. Tohidlu, \& R. Bakhtiari, Identification educational barriers to the development of entrepreneurial spirit in Zanjan University students. Journal of American Science, 8, 2012, 507-511.

[4]. I. Azjen, The theory of planned behavior. Organizational Behavior and Human Decision Processes, 50, 1991, $179-211$.

[5]. R.L. Engle, N. Dimitriadi, J. V. Gavidia, C. Schlaegel, S. Delano, I. Alvarado, . . . B. Wolff, Entrepreneurial intent: A twelvecountry evaluation of Azjen's model of planned behavior. International Journal of Entrepreneurial Behaviour and Research, 16, 2010, 35-57.

[6]. I. Azjen, Attitudes, personality and behavior (2nd ed.). (New York, NY: McGraw Hill, 2005)

[7]. R. D. Astuti, \& F. Martdianty, Students' entrepreneurial intentions by using theory of planned behavior: The case in Indonesia. The South East Asian Journal Management, 6(2), 2012, 100-112.

[8]. F. Bektas, Entrepreneurial intentions of Turkish university students. International Journal of Arts \& Sciences, 4(8), $2011,167-181$.

[9]. S. Wu, \& L. Wu, The impact of higher education on entrepreneurial intentions of university students in china. Journal of Small Business and Enterprise Development, 15, 2008, 752-774.

[10]. X. Quan, Prior experience, social network, and levels of entrepreneurial intentions. Management Research Review, 35, 2012, 945957.

[11]. Gelderen, V., Brand, M.; van Praag, V, Bodewes, W., Poutsma, E., Gils, A., Explaining entrepreneurial intentions by means of the theory of planned behavior. Career Development International, 13 (6), 2006, 538 - 559.

[12]. Raposo, M., \& Paco, A., Entrepreneurship education: Relationship between education and entrepreneurial activity. Psicothema, 23, 2011, 453-457.

[13]. European Commission. (2008). Best procedure project: Entrepreneurship in higher education, especially in non-business studies. 
Retrieved from http://ec.europa.eu/enterprise/entrepreneurship/support_measures/training_education/index.htm

[14]. Fayolle, A., \& Gailly, B. (2004, July). Using the theory of planned behavior to assess entrepreneurship teaching programs: A first experimentation. Paper presented at the 14th Annual IntEnt Conference, University of Napoli Federico II, Naples, Italy.

[15]. S.J. Hosseini, H. Ahmadi, \& M. O. Najafabadi, The perceptions of graduate students about factors influencing the extension of entrepreneurship education in college of agriculture and natural resources in Iran. Journal of American Science, 7, $2011,255-259$.

[16]. K. Hermann, P. Hannon, J. Cox,P. Ternouth, \& T. Crowley, (2008). Developing entrepreneurial graduates: Putting entrepreneurship at the centre of higher education. Retrieved http://www.ncee.org.uk/publication/developing_entrepreneurial_graduates.1.pdf

[17]. A. Nasurdin, N.H. Ahmad, \& C.E Lin (2009). Examining a model of entrepreneurial intention among Malaysians using SEM procedure. European Journal of Scientific Research, 33, 2009, 365-373.

[18]. F. Wilson, J. Kickul, \& D. Marlino, Gender, entrepreneurial self-efficacy, and entrepreneurial career intentions: Implications for entrepreneurship education. Entrepreneurship Theory and Practices Magazine, 31, 2007, 387-406.

[19]. I. Ahmed, M. Nawaz, Z. Ahmad, M. Z. Shaukat, A. Usman, W.U. Rehman \& N. Ahmed, Determinants of students' entrepreneurial career intentions: Evidence from business graduates. European Journal of Social Sciences, 15(2), 2010, 14-23.

[20]. G. Startiene, \& R. Remeikiene, The influence of demographical factors on the interaction between entrepreneurship and unemployment. 2009. Retrieved from http://www.ktu.edu/lt/mokslas/zurnalai/inzeko/64/1392-2758-2009-4-64-60.pdf

[21]. P. Brijlal, Entrepreneurial perceptions and knowledge: A survey of final year university students. African Journal of Business Management, 5, 2011, 818-825.

[22]. N. C. Bhandari, Relationship between students' gender, their own employment, their parents' employment, and the students' intention for entrepreneurship. Journal of Entrepreneurship Education, 15, 2012, 133-144.

[23]. Hamidi, D. Y., Wennberg, K., \& Berglund, H., Creativity in entrepreneurship education. Journal of Small Business and Enterprise Development, 15, 2008, 304-320.

[24]. M. Z. Ismail, Developing entrepreneurship education: Empirical findings from Malaysian polytechnics, doctoral diss., University of Hull, Yorkshire, United Kingdom, 2010.

[25]. Ministry of Higher Education, Dasar Pembangunan Usahawan: Institut Pengajian Tinggi . 2010, Retrieved from http://www.portal.mohe.gov.my/portal/page/portal/ExtPortal/MOHE_MAIN_PAGE/NEWSEVENTS/publication/dasar_pbgn_keus ahawanan_ipt.pdf (in Malay)

[26]. W. N Almobaireek \& T. S. Manolova, Who wants to be an entrepreneur? Entrepreneurial intentions among Saudi university students. African Journal of Business Management, 6, 2012, 4029-4040.

[27]. Malaysian Ministry of Higher Education. Indikator Pengajian Tinggi 2009-2010. [Higher Learning Indicator 2009-2010]. Retrieved from http://www.mohe.gov.my/web_statistik/indikator_pengajian_tinggi_2009-2010.pdf

[28]. Yusuf, W.F.W \& Lame, S.M. Entrepreneurship development programme in higher learning institution: A case study of Universiti Tun Hussein Onn Malaysia. Proceedings International Conference of Technology Management. 18-19 December 2012, Renaissance Hotel, Melaka, 693-707.

[29]. Z. Mohamed, G. Rezai, M.D. Shamsudin, \& M.M Mahmud, Enhancing young graduates' intention towards entrepreneurship development in Malaysia. Education + Training, 54, 2012, 605-618. 